\title{
ERYTHROPOIETIN FROM THE KIDNEY CELLS CULTURED IN VITRO
}

\author{
SHINJIRO OZAWA \\ Department of Internal Medicine, School of Medicine \\ Keio University, Tokyo, Japan
}

(Received for publication October 19, 1967)

The existence of a humoral factor stimulating erythropoiesis has been widely confirmed and many experimental evidences have indicated that the kidney is a major source of this factor. ${ }^{1,2,5,6,13}$ In those studies, however, the bioassey is inevitably needed for the determination of erythropoietic activity in the materials originated from the kidney. ${ }^{7,8,8,10}$

In the present study, the further improvement was made by using the parabiotic culture system, in which the kidney and bone marrow cells were cultured together in the same culture tube containing ${ }^{59} \mathrm{Fe}$, and Heme ${ }^{59} \mathrm{Fe}$ synthesis was observed as an index of erythropoietin activity. In this method, all experimental procedures were performed in vitro and the direct effect of the kidney cells on the bone marrow cells can be observed without any interference of other organs.

\section{MATERIAL AND METHODS}

Culture Media: 1) Eagle's basal medium with 10\% rabbit serum (Eagle's $\mathrm{BM}+10 \% \mathrm{RS}$ ) was used in the bone marrow cell culture and parabiotic cultures. 2) Eagle's basal medium with $10 \%$ calf serum (Eagle's BM+10\% CS) was used in the primary culture and subculture of the kidney or spleen cells. 3) $0.5 \%$ lactalbumin hydrate and $0.1 \%$ yeast extract in Earle's balanced salt solution with $20 \%$ calf serum ( $\mathrm{YLE}+20 \% \mathrm{CS}$ ) was used in the primary culture and subculture of the liver cells. In all medium, $\mathrm{pH}$ was adjusted to 7.4 by addition of sodium bicarbonate solution before culture.

Trypsin: Stock trypsin solution was made by dissolving $0.25 \mathrm{~g}$ of "Difco" trypsin in $100 \mathrm{ml}$ of balanced salt solution, this was used for trypsinization of 
tissues or cultured cells to be dispersed.

Cobalt: Cobalt chloride was added in the medium in various concentration $5 \mu \mathrm{M}$ to $0.001 \mu \mathrm{M}$ per tube.

Tissue culture: Kidney was obtained from new born rabbit, the tissue containing medulla and cortex was cut to small pieces 0.5 to $1.0 \mathrm{~mm}$ diameter and suspended in the trypsin solution stiring by magnetic stirrer at $37^{\circ} \mathrm{C}$, the time for trypsinization was about 15 to 20 minutes. The solution was then added equal volume of the culture medium and filtrated through the gauze to separate off the tissue fragment. The filtrate, in which the kidney cells were suspended, was centrifuged at $600 \mathrm{rpm}$ in 5 minutes and supernatant was discarded, the cells thus obtained were resuspended in Eagle's BM+10\% CS at the concentration of $1-3 \times 10^{4}$ cells per $\mathrm{ml}$, and distributed in roller tubes $1.5 \mathrm{ml}$ per tube. After 24 hrs of stationary culture, rolling culture was followed in 10 days and the kidney cells have grown on the inner surface of the culture tube about $1-3 \times 10^{5}$ cells per tube. Spleen or liver cells suspension were prepared in the same trypsinization procedure described above. To establish the primary culture of those cells, three to four weeks were needed, and subculture was to be followed to obtain adequate numbers of the cells. Bottle culture was employed both in primary culture and subculture of liver cells and spleen cells, and the growth medium was renewed about twice a week. The culture history is recorded in Table 1. After

Table 1

Tissue Culture History of the Kidney, Spleen, and Liver Established from Rabbit

\begin{tabular}{|c|c|c|c|c|}
\hline Tissue & $\begin{array}{l}\text { Culture } \\
\text { medium }\end{array}$ & $\begin{array}{c}\text { Culture } \\
\text { generation }\end{array}$ & $\begin{array}{c}\text { Duration } \\
\text { (days) }\end{array}$ & Date \\
\hline Kidney & $\begin{array}{c}\text { Eagle's Med. } \\
+ \\
10 \% \mathrm{CS}\end{array}$ & Primary culture & & \\
\hline \multirow{5}{*}{ Spleen } & \multirow{5}{*}{$\mu$} & 1 & 25 & June $2466^{\prime}$ \\
\hline & & 2 & 14 & July $18 "$ \\
\hline & & 3 & 10 & $\prime \prime 28 \prime \prime$ \\
\hline & & 4 & 11 & Aug. 8 " \\
\hline & & 5 & 10 & "/ $18 " \prime$ \\
\hline \multirow[t]{3}{*}{. } & & 1 & 28 & June $29 " \prime$ \\
\hline & & 2 & 14 & July 26 \\
\hline & YLE & 3 & 10 & Aug. $10 "$ \\
\hline \multirow[t]{4}{*}{ Liver } & + & 4 & 10 & $\|\quad 20 "\|$ \\
\hline & $20 \% \mathrm{CS}$ & 5 & 9 & $"$ " $29 \|$ \\
\hline & & 6 & 12 & Sep. $10 "$ \\
\hline & & 7 & 10 & $\| \quad 20 " l$ \\
\hline
\end{tabular}


ERYTHROPOIETIN FROM THE KIDNEY CELLS CULTURED IN VITRO 195

these subcultivations, the cells were resuspended in roller tube $1-3 \times 10^{1}$ cells per $\mathrm{ml}$ and cultured in the same procedure as kidney cells, thus the spleen or liver cells were grown in the tube $1-3 \times 10^{5}$ cells per tube.

Bone marrow cells: The method is a modification of $\mathrm{Krantzs}^{\prime}{ }^{3}$ cell were obtained from the femora of young rabbit weighting 0.8 to $1.0 \mathrm{~kg}$ by splitting the scrapped bones and removing the marrow with a thin spatula, the cells were suspended in the medium (Eagle's BM+10\% RS) by passages through a sylinge and mesh $^{3}$ until most of the cells were singly dispersed. The suspension of cells at a concentration of 3,000 cells per $\mathrm{mm}^{3}$ was used to the parabiotic culture. In the medium radioactive iron ${ }^{59} \mathrm{Fe}$ was added at a concentration of $1 \mu \mathrm{C}$ per tube.

Parabiotic culture: The parabiotic culture consisted of the complete removal of the old medium from the tubes in which the kidney, splcen or liver cells had been grown respectively; the addition of $1.5 \mathrm{ml}$ of bone marrow cell suspension with ${ }^{59} \mathrm{Fe} 1 \mu \mathrm{C}$ per tube; exchange of the air in the tubes with the gasmixture consisted of $\mathrm{N}_{2} 97 \%$ and $\mathrm{O}_{2} 3 \%$ or $\mathrm{N}_{2} 99 \%$ and $\mathrm{O}_{2} 1 \%$; and finally, rolling culture (parabiotic culture) in $24 \mathrm{hrs}$. The schema is shown in Fig. 1.

\section{Schema of the Parabiotic culture}

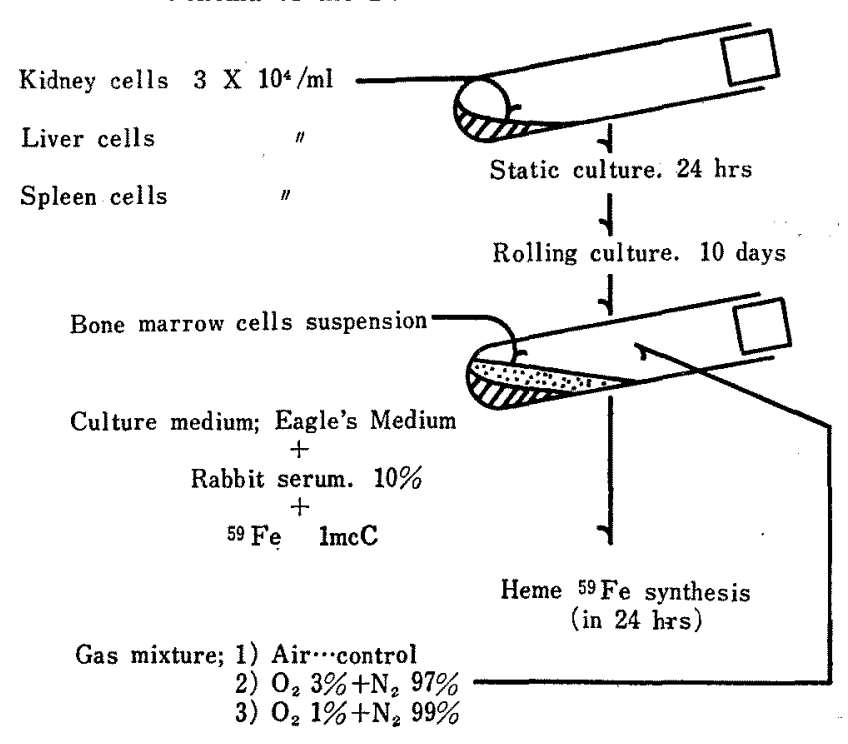

Fig. 1

Extraction of Heme: At the end of the indicated culture interval the bone marrow cell suspension were transferred to centrifuge tubes and washed 
with physical saline. Kidney, spleen or liver cells may be resuspended in this procedure but which did not interfere the end result. The packed cells were lysed by addition of $2 \mathrm{ml}$ of water and $0.5 \mathrm{ml}$ of Drabkin's solution ${ }^{12}$ and allowed to stand in the cold over night. The heme was extracted from the fluid with butanone- 2 by the method of Teale ${ }^{11}$ and Heme ${ }^{59} \mathrm{Fe}$ was counted in the well type scintillation counter.

pH and gas analysis: Sholander's microgas analyser and $\mathrm{pH}$ meter with glass electrode were used.

\section{RESULTS}

Heme ${ }^{59} \mathrm{Fe}$ synthesis of the bone marrow cells was decreased in anoxic state, on the other hand, Heme ${ }^{5} \mathrm{Fe}$ synthesis was increased when the bone marrow cells were cultured together with the kidney cells in anoxic state. Two kinds of gases were prepared to induce anoxic states, the gasmixture consisted of $97 \% \mathrm{~N}_{2}$ and $3 \% 0_{2}$ was most effective to accelerate the Heme ${ }^{59} \mathrm{Fe}$ synthesis in parabiotic culture, however, the gas consisted of $99 \% \mathrm{~N}_{2}$ and $1 \% \mathrm{O}_{2}$ was ineffective because of the extreme scantiness of oxygen and $\mathrm{Heme}{ }^{59} \mathrm{Fe}$ synthesis was supressed even in the parabiotic culture of the bone marrow and the kidney cells (Fig. 2). When rabbit serum was not used in the culture medium, the

Bone marrow culture

C. P. M.
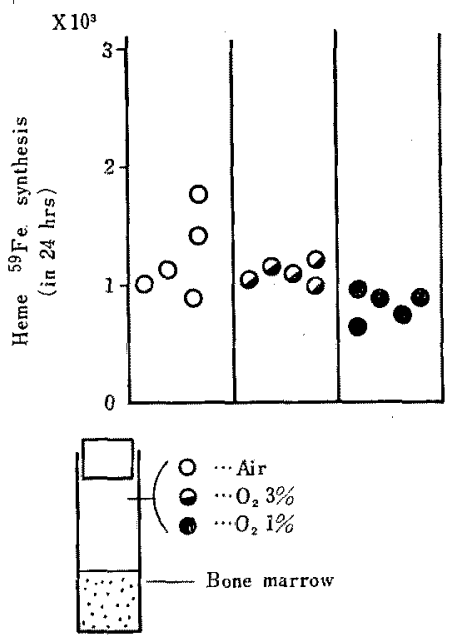

Parabiotic culture (Bone marrow \& Kidney cells)
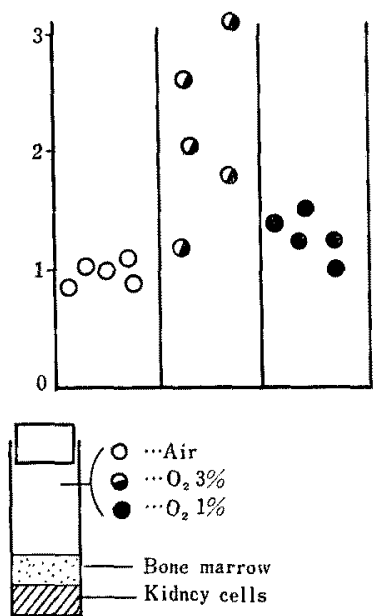

Fig. 2 


\section{ERYTHROPOIETIN FROM THE KIDNEY CELLS CULTURED IN VITRO 197}

Parabiotic culture

(Bone marrow \& Kidney cells)

C. P. M.

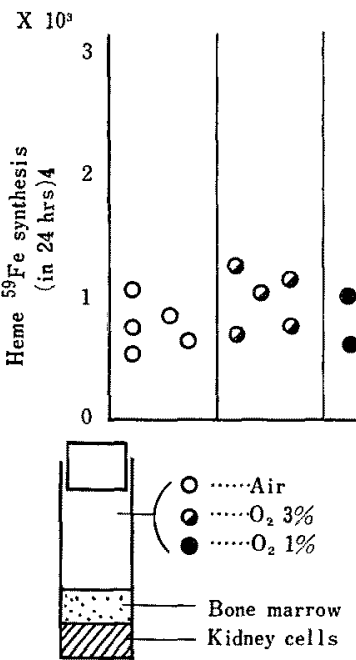

* Rabbit serum is not contained

in the culture medium.

Fig. 3

Parabiotic culture

C. P. M. (Bone marrow \& Liver cells) (Bone marrow \& Spleen cells)

$\mathrm{X} 10^{3}$
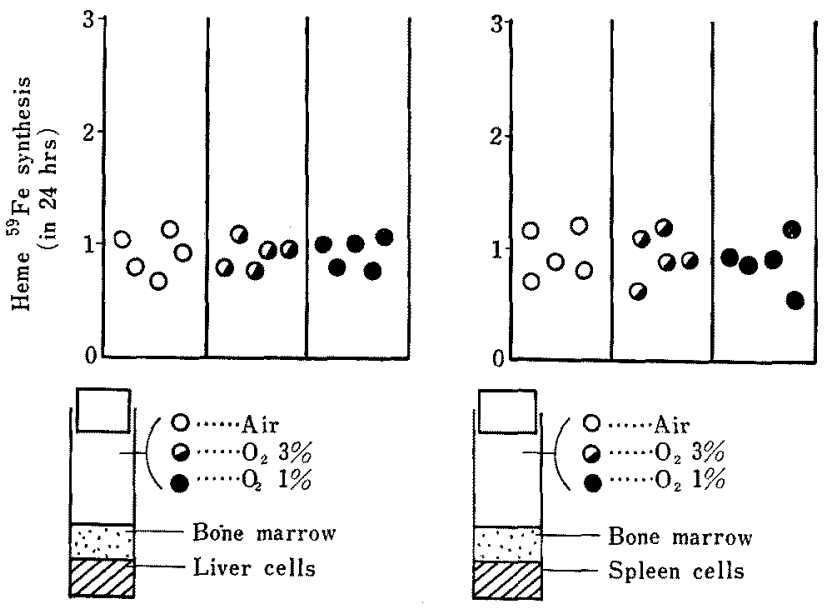

Fig. 4 
acceleration of Heme ${ }^{59} \mathrm{Fe}$ synthesis did not occured in anoxic state (Fig. 3). In the parabiotic culture of the bone marrow cells and the spleen cells or liver cells, anoxia did not increase the Heme ${ }^{59} \mathrm{Fe}$ synthesis (Fig. 4). When cobalt chloride was administered in the bone marrow cell culture, Heme ${ }^{59} \mathrm{Fe}$ was significantly supressed. However, in the parabiotic culture of the bone marrow cells and kidney cells there seemed to exist the optimum concentration of cobalt $(0.01-$ $0.001 \mu \mathrm{M}$ ) accelerating Heme ${ }^{59} \mathrm{Fe}$ synthesis (Fig. 5). Cobalt chloride was administered in the parabiotic culture of the bone marrow cells and spleen or liver cells, there was no elevation of Heme ${ }^{59} \mathrm{Fe}$ synthesis in any concentration of cobalt (Fig. 6). Effect of the medium $\mathrm{pH}$ in Heme ${ }^{59} \mathrm{Fe}$ synthesis was observed. 1) In the parabiotic culture of the kidney cells and bone marrow cells, the medium $\mathrm{pH}$ and gas analysis were observed after $24 \mathrm{hrs}$ of culture, Table 2 showed that the medium $\mathrm{pH}$ was lowered to 6.8 in control, on the contrary, the $\mathrm{pH}$ was remained $7.8-7.6$ in anoxic state. 2) Heme ${ }^{59} \mathrm{Fe}$ synthesis in bone marrow cells culture was compared between in medium $\mathrm{pH} 6.8$ and $7.8, \mathrm{pH}$ was adjusted respectively by addition of sodium bicarbonate in the medium before

Effect of Cobalt on Heme ${ }^{59} \mathrm{Fe}$ synthesis

C. P.M.
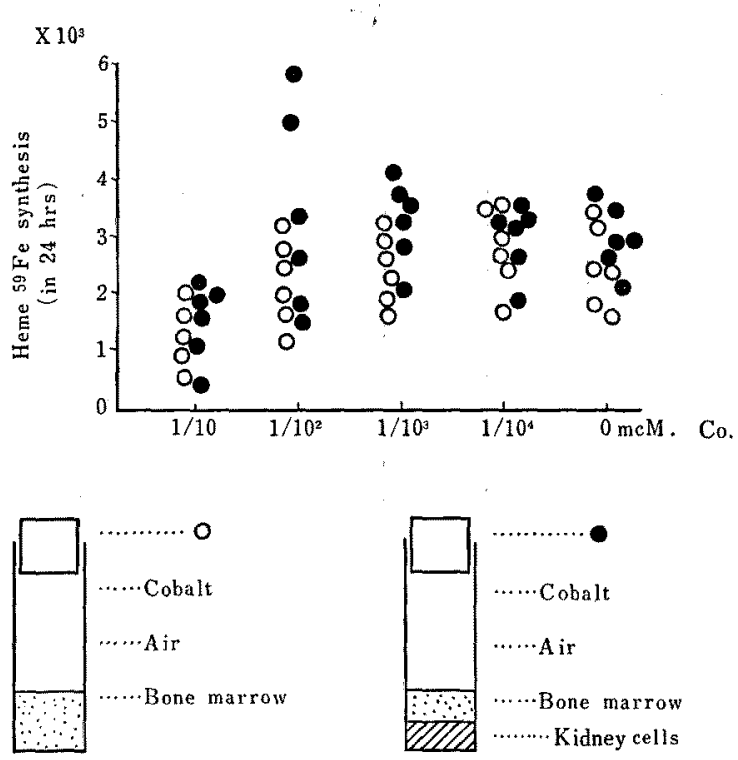

Fig. 5 
C. P. M.
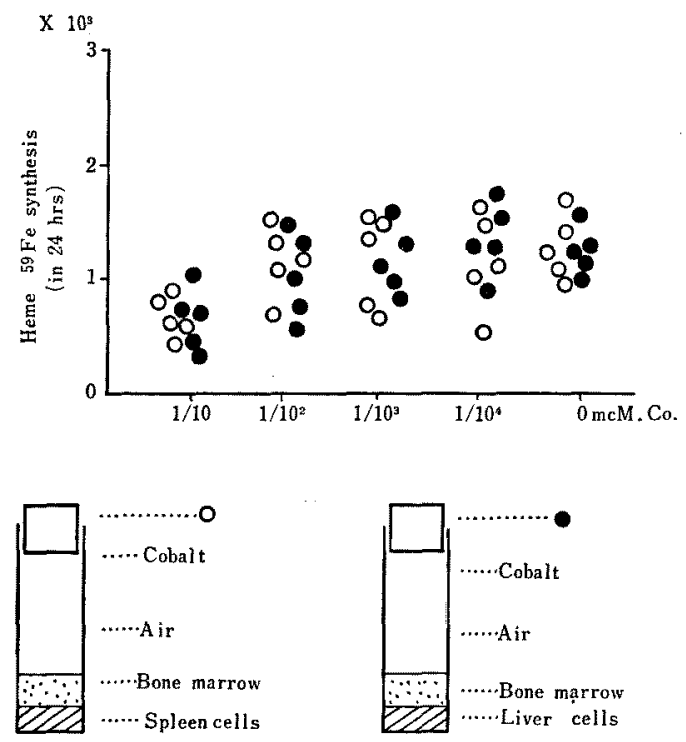

Fig. 6

Table 2. $\mathrm{pH}$, Gas-concentration and Heme ${ }^{59} \mathrm{Fe}$ Synthesis

(in $24 \mathrm{hrs)}$

\begin{tabular}{|c|c|c|c|c|c|c|c|}
\hline EDa & $\begin{array}{l}\cdots \cdot \mathrm{O}_{2} 3 \% \\
\cdots \cdots \text { Kidney cells }\end{array}$ & $\begin{array}{l}\text { No } \\
1 \\
2 \\
3 \\
4 \\
5\end{array}$ & $\begin{array}{l}\mathrm{CO}_{2} \% \\
0 \\
0.33 \\
0 \\
0.22 \\
0.17\end{array}$ & $\begin{array}{l}\mathrm{O}_{2} \% \\
4.85 \\
4.58 \\
4.67 \\
6.64 \\
7.01\end{array}$ & $\begin{array}{l}\mathrm{PcO}_{2} \\
0 \\
2.4 \\
0 \\
1.6 \\
1.2\end{array}$ & $\begin{array}{c}\mathrm{Po}_{2} \\
34.6 \\
32.7 \\
33.2 \\
47.3 \\
50.0\end{array}$ & $\begin{array}{l}\mathrm{pH} \\
7.72 \\
7.56 \\
7.68 \\
7.68 \\
7.68\end{array}$ \\
\hline$E D$ & $\begin{array}{l}\cdots \cdots \mathrm{O}_{2} \cdots \text { Air } \\
\cdots \cdots \text { Kidney cells }\end{array}$ & $\begin{array}{l}1 \\
2 \\
3 \\
4 \\
5\end{array}$ & $\begin{array}{l}0.27 \\
0.14 \\
0.34 \\
0.27 \\
0.56\end{array}$ & $\begin{array}{lll}2 & 0.0 & 7 \\
2 & 0.4 & 3 \\
2 & 0.1 & 5 \\
2 & 0.1 & 5 \\
2 & 0.0 & 9\end{array}$ & $\begin{array}{l}1.9 \\
1.0 \\
2.3 \\
1.9 \\
4.0\end{array}$ & $\begin{array}{lll}1 & 4 & 3.2 \\
1 & 4 & 5.0 \\
1 & 4 & 4.2 \\
1 & 4 & 3.4 \\
1 & 4 & 2.6\end{array}$ & $\begin{array}{l}7.39 \\
7.49 \\
7.43 \\
7.51 \\
7.38\end{array}$ \\
\hline \% & 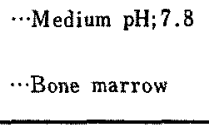 & & & & & & \\
\hline$\square$ & $\begin{array}{l}\text { Medium pH; } 7.2 \\
\cdots \text { Bone marrow }\end{array}$ & & , & 2 & 4 & $b^{6 x}$ & $\begin{array}{l}\text { C. P. M. } \\
\text { Fe synthesis } \\
24 \text { hrs) }\end{array}$ \\
\hline
\end{tabular}


culture. Table 2 showed Heme ${ }^{50} \mathrm{Fe}$ synthesis was more increased in $\mathrm{pH} 6.8$ than in $\mathrm{pH} 7.8$. The incorporation of ${ }^{59} \mathrm{Fe}$ in the kidney cells was measured (Fig. 7).

Medium $\mathrm{pH}$ and Incorporation of ${ }^{59} \mathrm{Fe}$ into Kidney cells

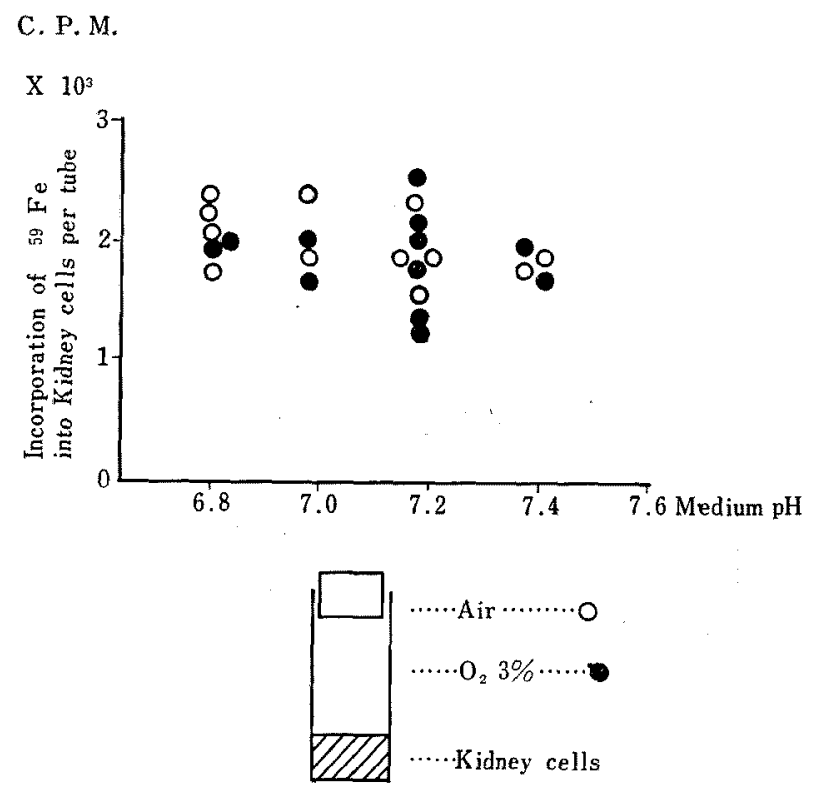

Fig. 7

\section{DISCUSSION}

In the parabiotic culture of the bone marrow cells and kidney cells, Heme ${ }^{59} \mathrm{Fe}$ synthesis was accelerated when those cells were cultured in anoxic state, while, this response was not found in the parabiotic culture of the bone marrow cells and spleen or liver cells. From those results it seems probable that kidney cells cultured in anoxic state showed a specific property releasing a humoral substance which directly stimulate hemoglobin synthesis of the bone marrow cells, and it seemed unlikely that erythropoietin is produced as an inactive precurser by kidney cells and is activated by some other tissue, since other tissue was not exist in this parabiotic culture except bone marrow cells and kidney cells. It is of interest that no erythropoietic activity was demonstrated in the parabiotic culture of the bone marrow cells and kidney cells in anoxic state, when serum was not contained in the culture medium. Whether the kidney or bone marrow cells need the serum component ${ }^{14}$ as a nonspecific nutrient or 
the kidney cells activate some precursor substances in the serum to produce erythropoietin, is remained unexplained. A similar hypothesis has been proposed by Contrera et al. ${ }^{9}$

In these experimental system, however, Heme ${ }^{59} \mathrm{Fe}$ synthesis of the bone marrow cells were also controlled by the medium $\mathrm{pH}$ and iron metabolism of the partner cells (kidney, liver or spleen cells). In closed culture tube, $\mathrm{pH}$ was influenced by the concentration of $\mathrm{CO}_{2}$ produced by the cultured cells, and the respiration rate was strictly controlled by oxygen supply, therefore, the oxygen concentration plays an important role on the medium $\mathrm{pH}$ and finally on Heme ${ }^{59} \mathrm{Fe}$ synthesis. Table 2 showed that, in the kidney cell culture, $\mathrm{pH}$ was remained at 7.8 in anoxic state, and was lowered to 6.8 in control. However in bone marrow cell culture, Heme ${ }^{59} \mathrm{Fe}$ synthesis was more increased in $\mathrm{pH} 6.8$ than $\mathrm{pH}$ 7.8. These experiments posturated that Heme ${ }^{59} \mathrm{Fe}$ synthesis must be more increased in sufficient oxygen supply than in anoxic condition. However, the results obtained in parabiotic culture was contrary to this expectation and from those results it was concluded that the increase of Heme ${ }^{59} \mathrm{Fe}$ synthesis in anoxic state had not be induced by change of $\mathrm{pH}$.

In the parabiotic culture, radio iron was distributed into erythroblasts, other bone marrow cells, partner cells (kidney, spleen, liver cells) and medium. If considerable amount of radio iron was incorporated into the partner cells and was influenced by oxygen supply or medium $\mathrm{pH}$, this becomes to be another parameter which may control Heme ${ }^{59} \mathrm{Fe}$ synthesis. In the present study, however, no correlation was found between iron incorporation into kidney cells and oxygen supply or $\mathrm{pH}$, and it was concluded that Heme ${ }^{59} \mathrm{Fe}$ synthesis was not dependent on those factors (Fig. 7).

Cobalt, which is per se toxic for bone marrow cells, have been used as a stimulant of the erythropoietic activity, ${ }^{1,2}$ and since Jacobson's study ${ }^{4}$ indicated that erythropoietic activity was not increased in the plasma from the nephrectomized rat injected cobalt chloride, the effect of cobalt on kidney cells was also studied here using parabiotic culture system. Fig. 5 seemed to show a slight increase in Heme ${ }^{59} \mathrm{Fe}$ synthesis in the parabiotic culture of the bone marrow cells and kidney cells by administration of cobalt $0.01 \mu \mathrm{M}$ to $0.001 \mu \mathrm{M}$, however, this is not significant and those study needed to be confirmed by further experiment, because bone marrow cells were exposed to cobalt in this parabiotic system.

The identification of the cultured cells is the most fundamental problem in the present experiment, however, the difficulty of morphorogical identification of those cells, this problem was remained uncertain. 
Further experiment is made to clarify what kind of cell of the kidney are essential in the production of erythropoietin using parabiotic culture. As Fig. 8 shows, Heme ${ }^{59} \mathrm{Fe}$ synthesis is increased in parabiotic culture of cortex of kidney and bone marrow in anoxic state, however, no response was observed in parabiotic culture of medulla of kidney and bone marrow. These results indicates that cortex of kidney is need for erythropoietin production.

Parabiotic culture; (Cortex of Kidney \& Bone marrow)

; (Medulla of Kidney \& Bone marrow)

C. P.M.

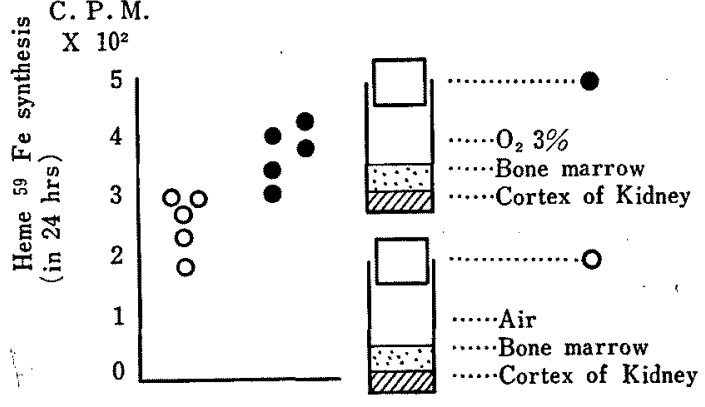

C. P.M.

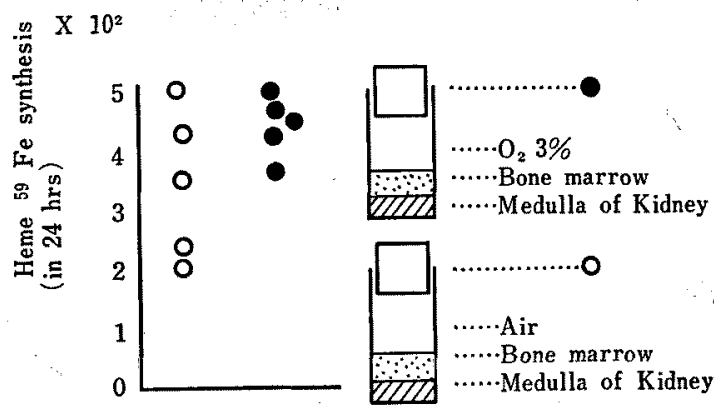

Fig. 8

\section{SUMMARY}

1) The kidney cells and bone marrow cells were cultured together in the same culture tube containing ${ }^{59} \mathrm{Fe}$, and Heme ${ }^{59} \mathrm{Fe}$ synthesis was observed in vitro. When they were cultured in anoxic state, Heme ${ }^{59} \mathrm{Fe}$ synthesis was increased. And when the serum was not used in the culture medium, this 


\section{ERYTHROPOIETIN FROM THE KIDNEY CELLS CULTURED IN VITRO 203}

response was not observed.

2) The parabiotic culture with other cells were studied as a control; The liver cells or spleen cells and bone marrow cells were cultured together in anoxic state, however, Heme ${ }^{59} \mathrm{Fe}$ synthesis was not increased.

3) Cobalt chloride was added in the cultured medium, there is no significant elevation of Heme ${ }^{59} \mathrm{Fe}$ synthesis even in the parabiotic culture of the bone marrow cells and kidney cells.

4) Cortex of kidney produces erythropoietin in anoxic state.

\section{REFERENCES}

1. Jacobson, L.O. and Doyle, M.: Erythropoiesis. Grune \& Stratton, 1962. New York and London.

2. Lange, Robert D. and Vera Pavlovic-Kentera: Erythropoietin of kidney. Editors Moore, C.V. and Brown, F.B., Progress in Hematology, Vol. IV. 72-96. Grune \& Stratton 1964. New York and London.

3. Krantz, S.B, et al.: The effect of erythropoietin upon Heme synthesis by marrow cells in vitro. J. Biol. Chem., 238: 4085-4090, 1963.

4. Jacobson, L.O. et al.: Role of the kidney in erythropoiesis. Nature, 179: 633$634,1957$.

5. Naets, J.P. et al.: Effect of anaemic anoxia on erythropoiesis of nephrectomized dog. Nature, 195: 190, 1962.

6. Rosse, W.F. et al.: The role of the kidney in the erythropoietic response to hypoxia in parabiotic rats. Blood, 19: 75-81, 1962.

7. Kuratowska, Z. et al.: Studies on the production of erythropoietin by isolated perfused organs. Blood, 18: 527-534, 1961.

8. Reismann, K.R. et al.: Erythropoietin formation isolated kidneys and liver. In Jacobson, L.D. and Doyle, M. (Eds.) Erythropoietis, New York, Grune \& Stratton, 71-77, 1962.

9. Contrera, J.F. et al.: Extraction of erythropoietin from kidneys of hypoxic and phenylhydrazine-treated rats. Blood, 25: 809-816, 1965.

10. Contrera, J.F. et als: Extraction of an erythropoietin-producing factor from a particulate fraction of rat kidney. Blood, 28: 330-343, 1966.

11. Teale, F.W.: Cleavage of the haem-protein link by acid methylethylketon. Biochim. et Biophys. Acta., 35: 543, 1959.

12. Wintrobe, M.M.: Clinical hematology. 5th edition. Lea \& Febiger, Philadelphia, $395,1961$.

13. Fisher, J.W. et al.: Effect of renal hypoxia on erythropoietin production. Brit. J. Haemat., 11: 382-388, 1965.

14. Woodliff, H.J.: Blood and bone marrow cell culture. 72 p. Eyre \& Spottiswoode, 1964, London. 